Ks. Bogdan CZYŻEWSKI

(Gniezno, UAM)

\title{
ŚWIĘTY BENEDYKT W WYPOWIEDZIACH JANA PAWLA II
}

\section{OGÓLNA CHARAKTERYSTYKA DOKUMENTÓW PAPIESKICH O ŚW. BENEDYKCIE}

Papieże XX i XXI wieku poświęcili św. Benedyktowi z Nursji kilka ważnych dokumentów, co wskazuje na jego ogromne znaczenie dla Kościoła i świata ${ }^{1}$. Otrzymał także wiele tytułów, które bywają niekiedy zapomniane na tle jednego, najbardziej eksponowanego, zwłaszcza w ostatnich czasach. Mam tutaj na myśli określenie Benedykta jako Patrona Europy. Nazywany jest on także wyznawcą i mnichem, zakonodawcą, patriarchą Zachodu. W taki przynajmniej sposób mówi o nim papież Polak ${ }^{2}$.

Z pobieżnej nawet analizy różnych dokumentów Jana Pawła II, związanych z okresem antyku chrześcijańskiego, wynika, że osobie św. Benedykta poświęcił on wiele miejsca, zwłaszcza z okazji jego 1500. rocznicy narodzin. Można je podzielić według rangi, jaka została im nadana.

Pierwszym z nich jest List Apostolski rozpoczynający się od słów: Sanctorum Altrix (= „Żywicielka Świętych”) z 11 lipca 1980 roku $^{3}$, wydany z okazji 1500. rocznicy urodzin św. Benedykta. Jan Paweł II ukazuje w tym dokumencie tło historyczne działalności św. Benedykta i wskazuje jednocześnie na podobieństwa do dzisiejszej sytuacji społeczno-politycznej. Chodzi tutaj przede

${ }^{1}$ Por. np. Pius XII, Encyklika „Fulgens radiatur” w tysięczną czterechsetną rocznicę śmierci św. Benedykta, AAS 39 (1947) 137-155, tłum. A. Bober, w tegoż: Studia i teksty patrystyczne, Kraków 1967, 150-160; Paweł VI, List Apostolski „Pacis nuntius” ogłaszający św. Benedykta głównym Patronem Europy, AAS 56 (1964) 965-967, thum. A. Bober, w tegoż: Studia i teksty patrystyczne, s. 160-161; S. Longosz, Św. Benedykt w wypowiedziach Ojca Świętego Jana Pawta II, VoxP 2 (1982) z. 2, 47-50; A. Malinowski, Bibliografia polska św. Benedykta opata, tamże, s. 30-46.

2 Por. Jan Paweł II, O sens ludzkiego przeznaczenia. Homilia wygłoszona w Nursji 5-6 (23 III 1980), OsRomPol 1 (1980) nr 4, s. 17; przedruk w Nauczanie papieskie (= NP), red. E. Weron A. Jaroch, III/1, Poznań 1985, 283-284.

${ }^{3}$ List Apostolski ,Sanctorum Altrix” Ojca Świętego Jana Pawła II na 1500. rocznicę narodzin św. Benedykta, AAS 72 (1980) 777-791, przekład polski: OsRomPol 1 (1980), nr 12, s. 11-13; przedruk VoxP 2 (1982) z. 2, 7-27; NP III/2, 200-210. 
wszystkim o wewnętrzne rozbicie człowieka zagubionego w wirze otaczających go wydarzeń, który traci poczucie sensu i wartości swojego życia. Rozwiązania, na które wskazuje Benedykt, mogą służyć także dzisiaj za wzór postępowania.

Kolejnym dokumentem poświęconym Benedyktowi jest list z okazji rozpoczęcia obchodów 1500-lecia jego przybycia do Subiaco. Datowany jest na 7 lipca 1999 roku i skierowany został do tamtejszego opata o. Maura Meacci ${ }^{4}$. Papież podkreśla w tym dokumencie zasługi i dobrodziejstwa, jakie wspólnota zakonna otrzymała od św. Benedykta podczas jego pobytu w Subiaco. Na uwagę zasługuje także wezwanie Ojca Świętego, skierowane do wspólnot zakonnych, by odnowiły swe życie i powróciły do szlachetnych ideałów benedyktyńskich.

Oprócz listów dedykowanych osobie św. Benedykta Jan Paweł II jest autorem orędzia z dnia 10 marca 1980 r., skierowanego do opata zakonu na Monte Cassino - Martino Matronola - z okazji 1500. rocznicy urodzin Benedykta ${ }^{5}$. Papież nawiązuje w nim do tytułu „Patron Europy”, jaki otrzymał Opat z Nursji od papieża Pawła VI i jednocześnie wskazuje na wiarę chrześcijańską jako na czynnik, który służył jednoczeniu narodów i był wyrazem tejże jedności. Jan Paweł II zachęca mieszkańców Europy do budowania jedności, zarówno duchowej jak i moralnej, której fundamentem może być duch chrześcijański obecny jeszcze w narodach europejskich oraz nauka zawarta w Ewangelii.

Papież jest również autorem szeregu przemówień poświęconych osobie św. Benedykta. Jedno z nich wygłosił na Placu św. Benedykta w Nursji 23 marca 1980 r. podczas modlitwy Anioł Pański ${ }^{6}$. Okoliczności, które temu towarzyszyły, związane były z trzęsieniem ziemi, jakie nawiedziło okolice Nursji. Jan Paweł II wskazał w nim na postać św. Benedykta, która ukształtowała nowe oblicze ziemi, nie tylko Italii, ale także Europy. Przemówienie to stało się okazją do skierowania orędzia pokoju i wezwania ludzi do zaniechania nienawiści, terroryzmu i przemocy.

Kolejne przemówienie Jana Pawła II związane z postacią św. Benedykta wygłoszone zostało w czasie spotkania z przełożonymi wspólnot sióstr benedyktynek, które miało miejsce 11 września 1989 roku$^{7}$. Papież nawiązał w nim do głównych założeń Reguły Opata z Nursji i nakreślił podstawowe zadania dla sióstr pracujących na całym świecie.

${ }^{4}$ List z okazji rozpoczęcia benedyktyńskich obchodów 1500-lecia przybycia do Subiaco św. Benedykta, Patrona Europy (7 VII 1999), ,Cenobium” 14 (2000) 5-11.

5 Orędzie Ojca Świętego Jana Pawła II z okazji 1500-lecia urodzin św. Benedykta, AAS 72 (1980) 318-320, przekład polski: OsRomPol 1 (1980) nr 3, s. 1; „Kierunki” 26 (1980) nr 13, s. 2; NP III/1, 274-275.

${ }^{6}$ Przemówienie: Módlmy się o pokój, wolność i sprawiedliwość (23 III 1980), przekład polski w: Aniol Pański z papieżem Janem Pawtem II, Rzym 1982, 212-215.

${ }^{7}$ Reguła św. Benedykta programem życia również na dzisiaj. Przemówienie na III Międzynarodowym Sympozjum Przełożonych Wspólnot Sióstr Benedyktynek (11 IX 1998), „Via Consecrata" 2 (1999) nr 1, s. 4-5. 
Jan Paweł II wygłaszał także homilie z różnych okazji, których bohaterem była osoba św. Benedykta. Pierwszą z nich jest homilia wygłoszona na Monte Cassino niecały rok po rozpoczęciu pontyfikatu, mianowicie 18 maja 1979 roku $^{8}$. Okazją do jej wygłoszenia stała się pielgrzymka wraz z kapłanami byłymi więźniami obozów koncentracyjnych. Monte Cassino uznał papież za dostojny pomnik religijności i człowieczeństwa. Tutaj bowiem pielgrzymi odzyskują pokój ducha, nawiązują właściwe relacje z Panem Bogiem i drugim człowiekiem. Papież podkreślił także ogromne znaczenie orędzia św. Benedykta, które ciągle zachęca człowieka do prowadzenia głębokiego życia wewnętrznego. Ojciec Święty wskazał w niej również na jedność zmierzającą do budowania zjednoczonej Europy, która powinna występować na płaszczyźnie religijnej, ekonomicznej i kulturowej. Budować zaś jedność można na wspólnych dla całej Europy korzeniach.

Kolejną homilię poświęconą postaci św. Benedykta papież wygłosił 23 marca 1980 roku$^{9}$. Nawiązał w niej do 1500-lecia jego urodzin. Jan Paweł II ukazał osobę św. Benedykta w kontekście nowej ewangelizacji. Program przez niego ułożony stał się fundamentem chrystianizacji ludów ówczesnej mu Europy. Papież podkreślił także znaczenie i aktualność świętego w dzisiejszym świecie.

Jan Paweł II wygłosił także homilię poświęconą św. Benedyktowi 20 września 1980 r. na Monte Cassino w związku z obchodami roku św. Benedykta ${ }^{10}$. Papież mówił w niej o osiągnięciach św. Benedykta, które okazały się na tyle uniwersalne, iż objęły całą Europę. Powołał się przy tym na bardzo aktualną jego Regutę, która przyczyniła się do odnowy życia monastycznego, a także świeckiego.

\section{PRZESŁANIE DUCHOWE ŚW. BENEDYKTA}

Lektura i analiza wymienionych wyżej dokumentów papieża Jana Pawła II na temat św. Benedykta pozwala odnaleźć w nich dwa zasadnicze nurty, czy też inaczej mówiąc przesłania, które wynikają z życia i dzieła tego świętego. W nauczaniu Opata z Nursji papież dostrzega przesłanie duchowe i społeczne. Jan Paweł II zachęca bowiem, że 1500-lecie urodzin św. Benedykta stanowi dobrą okazję do „ponownego wsłuchania się w głoszoną przez niego naukę, zarówno duchową, jak i społeczną" ${ }^{11}$. Ojciec Święty wielokrotnie też nawiązy-

${ }^{8}$ Homilia: Budować wspólny dom (18 V 1979), przekład polski A. Gryczyńska, „W drodze” 8 (1981) nr 1, s. 10-14.

${ }^{9}$ Homilia: Odnaleźć sens ludzkiego przeznaczenia (23 III 1980), AAS 72 (1980) 268-274, przekład polski: OsRomPol 1 (1980) nr 4, s. 17-18; NP III/1, 281-284.

${ }^{10}$ Homilia: Wasze klasztory wspólnotami prawdziwej miłości (20 IX 1980), AAS 72 (1980) 1002-1007, przekład polski: OsRomPol 1 (1980) nr 12, s. 17; NP III/2, 355-358.

11 Sanctorum Altrix. Wstęp, OsRomPol 1 (1980) nr 12, s. 11, lub VoxP 2 (1982) z. 2, s. 7. 
wał w swoim nauczaniu do czasów, w których narodził się św. Benedykt. Była to bowiem z jednej strony epoka eksplozji życia zakonnego, religijnej wolności, wzrastania Kościoła „,na skutek tego duchowego fermentu” ${ }^{\text {, } 12}$, a z drugiej kultura państwowa ulegała rozprzężeniu, świat rzymski zaś chylił się ku upadkowi.

Papież z dużym naciskiem podkreślał, że w przesłaniu duchowym Opata z Nursji, bardzo ważne miejsce zajmował człowiek i jego niepowtarzalna godność jako osoby ${ }^{13}$. W związku $\mathrm{z}$ tym Jan Paweł II omawia trzy podstawowe elementy życia benedyktyńskiego: modlitwę, pracę i ojcowskie sprawowanie władzy.

1. Modlitwa. W nauczaniu św. Benedykta modlitwa była jednym z najważniejszych elementów życia mnichów benedyktyńskich, zgodnie z zasadą: ora et labora. Stanowiła ona zatem religijny motyw, tak bardzo wyeksponowany przez samego św. Benedykta i zauważony przez papieża Jana Pawła II. Chodzi tutaj przede wszystkim o tak zwaną „drogę życia”, na którą wskazuje św. Benedykt w Regule i zaleca jej praktykowanie swoim braciom. Papież wyjaśnia, iż „droga życia” polega na żarliwym, wiernym i gorliwym szukaniu Boga poprzez miłość do Chrystusa i zachowywanie pokory ${ }^{14}$.

Ojciec Święty dostrzega także w tak zwanej „drodze życia” zalecanej przez św. Benedykta charakterystyczną jej cechę, mianowicie potrzebę zachowania równowagi, z jednej strony pogodzenia samotności ze współżyciem z ludźmi, z drugiej zaś modlitwy z pracą. Dlatego Jan Paweł II przyznaje:
„Św. Benedykt nie wykłada jakichś czczych spekulacji teologicznych, lecz zaleca usilnie, jak zwykł to czynić, taki sposób myślenia i postępowania, który wynika z prawdy o otaczającej nas rzeczywistości, co prowadzi do wcielenia teologii w życie. Nie tyle pragnie on bowiem, by wiele rozmawiano o prawdach dotyczą- cych Chrystusa, ile raczej, by ludzie żyli rzeczywiście tajemnicą Chrystusową i wypływającym z niej chrystocentryzmem [...]. Człowiek bowiem wierny Bogu nie może zapomnieć o tym, co jest ludzkie; powinien więc być także wierny człowiekowi. Dlatego też obowiązki, które mamy do spełnienia na płaszczyźnie zwanej wertykalna - znajduje ona przede wszystkim swój wyraz w życiu modlitwy - są wtedy dopiero właściwie zrównoważone, gdy łączą się w należyty sposób z tym, co wymaga się od nas na płaszczyźnie horyzontalnej, gdzie największą rolę odgry- wa praca" 15 .

Aspekt religijny, do którego należy przede wszystkim modlitwa, uznaje papież za oś, „wokół której obraca się codzienna rzeczywistość i całe życie benedyktyńskie" 16 . Podstawą zaś modlitwy jest słuchanie słowa Bożego, przyjmowanie

\footnotetext{
12 Tamże I, OsRomPol nr 12, s. 11, VoxP z. 2, s. 8.

13 Por. tamże.

14 Por. tamże.

15 Tamże III, OsRomPol nr 12, s. 12, VoxP z. 2, s. 15.

16 Tamże IV, OsRomPol nr 12, s. 12, VoxP z. 2, s. 16.
} 
go z głęboką wiarą, pokorą i radością, i wreszcie prowadzenie swojego życia zgodnie z usłyszanym i przyjętym Bożym słowem. Słowo to winno przenikać do modlitwy prywatnej mnicha, ale także do całej pracy, którą on wykonuje oraz do tego wszystkiego, co staje się treścią całego jego życia. Papież zwraca uwagę, że sam św. Benedykt dawał temu wzór, co więcej nie tylko czytał słowo, które jest zawarte w Piśmie świętym, ale również odnajdywał je „w wielkiej księdze, jaką jest natura"17.

2. Praca. Ojciec Święty zwraca także uwagę na drugi bardzo ważny element duchowy życia mnichów benedyktyńskich, mianowicie na pracę. Jan Paweł II zauważa:

„Św. Benedykt podkreśla konieczność nadania pracy wymiaru duchowego i takiego rozszerzenia horyzontów ludzkiej działalności, aby stała się ona czymś więcej niż tylko wykonywaniem technicznych czynności i pogonią za własną korzyścią"18.

Opat z Nursji dostrzega także w tym wymiarze ludzkiej egzystencji potrzebę zastosowania Ewangelii. Papież miał tutaj na myśli troskę św. Benedykta o przywrócenie każdemu pełnych praw ludzkich, niezależnie od jego pochodzenia społecznego. Jan Paweł II zwracał uwagę:

„człowiek nie jest dla Benedykta jakąś anonimową maszyną, którą ktoś może się posługiwać dla osiągnięcia jak największych zysków, nie oceniając wykonywanej pracy według kryteriów moralnych i odmawiając wykonującemu ją słusznej zapłaty [...]. Benedykt natomiast uważa pracę, bez względu na to, z jakiego powodu się ją wykonuje, za część istotną życia i żąda, aby każdy mnich podejmował ją jako obowiązek sumienia" ${ }^{19}$.

Papież zauważył także, iż św. Benedykt włączył w ten sposób pracę do nadprzyrodzonego ujęcia życia, co więcej ,dopomógł człowiekowi, by uznał się za współpracownika Boga, a nawet stał się nim naprawdę, przez co każda twórcza praca musi prowadzić do pełnego rozwoju jego osobowości" 20 .

Najgłębsze zatem znaczenie słów ora et labora polega na połączeniu dwóch najważniejszych elementów życia, zarówno dla mnicha, jak i dla człowieka świeckiego. Papież podkreśla, że współczesny świat, gdyby mógł i zechciał na nowo odkryć wartość tej zasady, na wiele nurtujących go problemów spojrzałby z zupełnie innej perspektywy. Człowiek mógłby uznać siebie za współpracownika Boga, a praca stanowiłaby źródło rozwoju jego osobowości. W ten sposób, stając bliżej Boga, stawałby się człowiekiem w pełnym tego słowa znaczeniu ${ }^{21}$.

\footnotetext{
17 Tamże IV, OsRomPol nr 12, s. 12, VoxP z. 2, s. 18.

18 Tamże V, OsRomPol nr 12, s. 13, VoxP z. 2, s. 22.

19 Tamże V, OsRomPol nr 12, s. 13, VoxP z. 2, s. 20.

${ }^{20}$ Tamże V, OsRomPol nr 12, s. 13, VoxP z. 2, s. 20-21.

21 Por. tamże.
} 
W związku z tematem pracy papież wskazuje na negatywne zjawiska dotykające współczesny świat:

„Pracę można oderwać od modlitwy i uczynić ją jedynym wymiarem ludzkiej egzystencji [...]. Społeczeństwa i ludzie stali się na przestrzeni tych piętnastu stuleci, jakie dzielą nas od daty narodzin św. Benedykta z Nursji, spadkobiercami wielkiej cywilizacji - spadkobiercami jej zwycięstw, ale i klęsk, jej świateł, ale i mroków. Wyczuwa się przewagę ekonomii nad moralnością. Przewagę doczesności nad duchowością. Z jednej strony, wyłączne prawie nastawienie na konsumpcję dóbr materialnych odbiera głębszy sens życiu ludzkiemu. Z drugiej strony, praca staje się przymusem człowieka podporządkowanego kolektywom, a tę pracę za wszelką cenę odrywa się od modlitwy, odbierając również życiu ludzkiemu pozadoczesny sens" 22 .

Ojciec Święty zwraca zatem uwagę na konieczność dostrzeżenia w pracy jej wymiaru w pełni ludzkiego. Związana jest ona z człowiekiem, a więc powinna brać pod uwagę zarówno czynnik materialny jak i duchowy. Takie było bowiem rozumienie pracy przez św. Benedykta, który polecił mnichom zachować zasadę ora et labora.

W życiu zakonnym św. Benedykt nikogo nie ograniczał w realizacji posiadanych przez niego talentów. Każdy mógł się wykazać tym, czym został najbardziej uzdolniony. Wprowadził też odmienny, od istniejącego we współczesnym mu świecie, pogląd na pracę. Połączył ją mianowicie z modlitwą i wskazał przez to na jej ogromną wartość w życiu ludzi. Św. Benedykt udowodnił także, że człowiek przez pracę połączoną z modlitwą, współpracuje z Panem Bogiem i wypełnia w ten sposób polecenie, jakie zostawił mu Stwórca, by czynił sobie ziemię poddaną. Opat z Nursji zauważył także, iż praca pozbawiona elementu duchowego, czyni z człowieka zniewoloną maszynę i przez to odbiera mu godność osoby ludzkiej. Działalność człowieka powinna być czymś więcej, niż tylko technicznym wykonywaniem pewnych czynności, których celem jest pomnażanie własnych dóbr ${ }^{23}$. Wezwanie zatem św. Benedykta do nadania pracy wymiaru duchowego, który pozwoli człowiekowi przez pracę realizować swoje powołanie, staje się niezmiernie aktualne, co podkreśla Jan Paweł II omawiając dzieło Opata z Nursji.

3. Ojcowskie sprawowanie władzy. Trzeci wreszcie element duchowego życia benedyktyńskiego, na który zwraca uwagę papież, to ojcowskie sprawowanie władzy przez opata. Jan Paweł II przypomniał w tym względzie postać samego Benedykta, a także mówił o każdym innym opacie, który we wspólnocie powinien pełnić funkcję Dobrego Pasterza. Dlatego też spoczywa na nim

22 Homilia: Odnaleźć sens ludzkiego przeznaczenia 6 (23 III 1980), OsRomPol 1 (1980) nr 4, s. 18; NP III/1, 284.

23 Por. Sanctorum Altrix V. 
obowiązek, aby w podejmowaniu decyzji dotyczących spraw duchowych czerpał światło z Bożego słowa, nie zaniedbywał spraw doczesnych rodziny monastycznej i zarządzania jej dobrami materialnymi, pilnie dbał o poziom duchowy każdej osoby we wspólnocie ${ }^{24}$.

Należy także dostrzec drugą stronę zaleceń św. Benedykta, przypomnianych przez Jana Pawła II, a kierowanych zarówno do opata, jak też do wszystkich mnichów. Przepisy zawarte w Regule przyczyniły się nie tylko do odnowy życia mniszego, ale rzuciły również jasne światło dla rozwoju myślenia i obyczajów w duchu Ewangelii Chrystusowej. Cała Reguła zawiera bardzo proste i klarowne wskazania. Dzięki temu jej treść stała się zrozumiała dla wszystkich, którzy po nią sięgają. To sprawia, że nabierają one charakteru uniwersalnego. Także dziś wskazania św. Benedykta pomagają mnichom i ludziom świeckim w rozwoju ich duchowości oraz są pomocne w pogłębianiu swego osobistego kontaktu z Bogiem. Aby jednak wypełnianie tych nakazów przyniosło pożądane skutki, muszą być one wykonywane w duchu posłuszeństwa i pokory, z wewnętrzną radością. Podejście do tych zaleceń w taki właśnie sposób gwarantuje przynoszenie dobrych owoców dla duszy i szeroko rozumianej duchowości człowieka ${ }^{25}$.

Należy podkreślić jeszcze jeden ważny aspekt przesłania duchowego św. Benedykta, o którym wspomina papież. Ojciec Święty zauważa, iż Opat z Nursji potrafił odczytywać znaki czasów, w których przyszło mu żyć, a czynił to zwłaszcza w perspektywie wieczności. Dlatego też nazywa go apostołem Królestwa Bożego, ku któremu dąży każdy człowiek. Jan Paweł II zapewnia:

„Benedykt z pewnością czytał przenikliwie znaki ówczesnych czasów, kiedy układał swą Regutę, w której zespolenie modlitwy i pracy ma stawać się dla tych, co ją przyjmują, zasadą dążenia do wieczności" ${ }^{26}$.

\section{PRZESŁANIE SPOŁECZNE ŚW. BENEDYKTA}

Drugie przesłanie związane z osobą św. Benedykta, na które zwraca uwagę papież Jan Paweł II, nazwane jest społecznym. Wiąże się ono z tytułem, jaki otrzymał Opat z Nursji, mianowicie „Ojciec i nauczyciel Europy”.

Ojciec Święty nawiązał do Europy czasów św. Benedykta, która stanowiła „,jedność narodów, opierającą się na powszechnej wierze chrześcijańskiej”. Narody te „,czuły się chrześcijańskimi, wszystkie wyznawały wiarę w Boga, wszyst-

${ }^{24}$ Por. tamże.

25 Por. Homilia: Wasze klasztory wspólnotami prawdziwej miłości (20 IX 1980), OsRomPol 1 (1980) nr 12, s. 17; NP III/2, 355-358.

${ }^{26}$ Homilia: Odnaleźć sens ludzkiego przeznaczenia 5 (23 III 1980), OsRomPol 1 (1980) nr 4, s. $18 ;$ NP III/1, 283. 
kie dzięki wierze czuły się dziećmi tego samego Ojca Niebieskiego i należały do Kościoła Rzymskiego" "27. Jan Paweł II, kiedy mówił o jedności Europy, wskazywał na znaczenie św. Benedykta i założonego przez niego zakonu dla budowania tej jedności. Zawdzięczamy Jemu - jak zaznaczył papież - budowę jedności moralnej i duchowej Europy. Jan Paweł II przypomniał:

„po obaleniu Cesarstwa Rzymskiego Europa zrodziła się z ogromnego trudu, w którym nie mały udział mieli również on i mnisi zachowujący jego zasady życia. Milcząca, wytrwała i mądra praca owych mnichów przyczyniła się zarówno do zachowania kulturalnego dziedzictwa antyku, jak i do przekazania go ludom Europy, a także całej ludzkości. Tak więc duch benedyktyński, [...] jest czymś całkowicie przeciwnym duchowi zniszczenia, dlatego też ten Ojciec Europy napomina wszystkich mogących coś w tej sprawie uczynić, aby gorliwie rozwijali dobra, które prawdziwie żywią umysły, broniąc je zarazem wszelkimi siłami przed tym, co niszczy i zniekształca" 28 .

Papież przypomniał także tytuł użyty przez Piusa XII w odniesieniu do św. Benedykta, mianowicie „zwiastun pokoju”. Jan Paweł II zachęcał do wpatrywania się w postać św. Benedykta, który „przemawia zwłaszcza do ludów Europy, dążących w sposób roztropny do umacniania wzajemnej jedności"29. W tym kontekście, Ojciec Święty zaznaczył również:

„podstawą pokojowego współżycia, do jakiego musimy koniecznie dążyć, są przede wszystkim sprawiedliwość, prawdziwa wolność, wzajemna zgoda, braterska pomoc - a odnajdujemy je właśnie w nauce Ewangelii” ${ }^{30}$.

Należy jeszcze dodać, że św. Benedykt otrzymał również inne określenia, jakimi zwracał się do niego papież. Nazywał go „,znakomitym mężem”, „Rzymianinem”, „Europejczykiem” i „chwałą Kościoła”31. Tytuły te świadczą o ogromnym znaczeniu św. Benedykta, nie tylko dla Europy tamtych czasów, ale także dla Europy dzisiejszej, która jednoczy się i poszukuje wspólnych korzeni.

Wysiłki w kierunku budowania wspólnej zjednoczonej Europy dostrzegamy także w czasach obecnych. Nie zawsze jednak próbuje się budować tę jedność w oparciu o chrześcijańskie podstawy, które przecież w historii stały się przyczyną zjednoczenia wielu narodów. Kieruje się dziś zachętę, aby spoglądając w przeszłość i wracając do tego, co w niej chwalebne i dobre, na tym budować wspólnotę narodów. Nie można jej budować w oderwaniu od wiary chrześcijańskiej, która przecież leży u podstaw i korzeni ładu europejskiego.

${ }^{27}$ Orędzie z okazji 1500-lecia urodzin św. Benedykta (10 III 1980), OsRomPol 1 (1980) nr 3, s. 1; NP III/1, 274.
28 Sanctorum Altrix VI, OsRomPol nr 12, s. 13, VoxP z. 2, s. 26.
${ }^{29}$ Tamże VI, VoxP z. 2, s. 26-27.
30 Tamże, VoxP z. 2, s. 27.
31 Por. tamze VI, VoxP z. 2, s. 24-25. 
Wiara i jedność to dwa czynniki, które w powstawaniu wspólnoty europejskiej stają się czymś najistotniejszym ${ }^{32}$.

Drugie przesłanie społeczne, które papież zauważa w nauczaniu św. Benedykta, dotyczy pokoju. Nazwany on został przez Jana Pawła II ,zwiastunem pokoju i miłości”33. Społeczność, w której pielęgnuje się zasady zawarte w Regule, żyje w Duchu Ewangelii, czyli w pokoju, miłości i sprawiedliwości. Taka wspólnota - zdaniem papieża - nabiera odpowiedniego stosunku do świata i rzeczy, którym jest on napełniony ${ }^{34}$. Opat jako ojciec powierzonej sobie wspólnoty, pełniący w tym duchu swoją posługę, sprawi, że zapanuje w niej życzliwość i szacunek do wszystkich. To zaś stanowi podstawę i podłoże do budowania i umacniania pokoju między braćmi ${ }^{35}$.

Wszystkie wysiłki ziemskie prowadzą ludzi ku wyższym wartościom, co pozwala z kolei pogłębiać wolność i jedność. Prawdziwy zaś pokój - według Jana Pawła II - człowiek może osiągnąć dopiero wtedy, gdy uświadomi sobie, że sprawy Boże są najważniejsze w życiu doczesnym, a jako zasadę postępowania przyjmie prawdę, że prawo Ducha stoi nad prawem materii ${ }^{36}$.

Św. Benedykt podał bowiem proste i zrozumiałe wszystkim zasady postępowania, których celem było odzyskanie wewnętrznego, a co za tym idzie, i międzyosobowego pokoju. Oparł on swoje pouczenia o duchowość chrześcijańską. W jej centrum jest Bóg, człowiek natomiast otwierając się na Niego przez zdobyte cnoty, może odzyskać wewnętrzną jedność, a ta z kolei poprowadzi go do życia w pokoju. Żyjąc w taki sposób, człowiek staje się przykładem i wzorem. Sprawia, że reprezentowane przez niego wartości obecne są w otaczającym świecie. Dobro zaś, które stało się jego udziałem, rozszerza się na całe społeczności. W ten sposób papież ukazuje, na przykładzie nauczania św. Benedykta, fundament duchowy, na którym powinno się budować pokój międzynarodowy. Należy także zauważyć, że osoby pełniące w świecie funkcje przywódcze powinny je, zdaniem papieża, wykonywać w stosunku do swoich podwładnych w duchu ojcostwa. W takiej sytuacji ludzie poczują braterskie więzi i w pokoju przystąpią odważnie i wielkodusznie do budowania lepszego świata, w którym człowiek odczuje, że jest bliskim współpracownikiem Boga ${ }^{37}$.

Szczególne miejsce w budowaniu pokoju w świecie przypada, zdaniem Jana Pawła II, wspólnotom zakonnym. Mnisi mają wsłuchiwać się w głos św. Benedykta i wypełniać polecenia przez niego ustanowione, a tym samym stawać się swego rodzaju źródłami, z których ma wytryskać pokój zarówno dla Kościoła, jak i dla całej wspólnoty ludzkiej. Aby tak się stało, powinni oni powracać

\footnotetext{
${ }^{32}$ Por. Homilia: Budować wspólny dom (18 V 1979), „W drodze” 8 (1981) nr 1, s. 14.

${ }^{33}$ Sanctorum Altrix II, OsRomPol nr 12, s. 11, VoxP z. 2, s. 13.

34 Por. tamże VI.

35 Por. tamże.

36 Por. tamże II.

${ }^{37}$ Por. tamże VI.
} 
i ciągle wszystko odnosić do Chrystusa, który jest jedynym źródłem prawdziwego pokoju. Również wszyscy ludzie, postępując w ten sposób i patrząc na całą rzeczywistość przez pryzmat Chrystusa, mogą osiągnąć upragniony pokój, który pozwoli na budowanie trwałej wspólnoty ${ }^{38}$. Będą mogli wówczas swoim postępowaniem przemieniać oblicze ziemi, na której pojawia się terroryzm i nie przestrzega się praw człowieka, zatraca się też wartość i godność pracy. Powrót i wzorowanie swego postępowania na wskazaniach św. Benedykta, a zatem szukanie Boga i odczytywanie wszystkiego w oparciu o prawdy zawarte w Ewangelii, stanie się zapewne możliwe i bardzo owocne w dobre skutki dla całej rodziny ludzkiej ${ }^{39}$.

Każdy człowiek świecki jest także wezwany do tego, aby wracać do przeszłości i czerpać z niej sprawdzone wzory. Za taki przykład - zdaniem Ojca Świętego - może służyć postać św. Benedykta. Pomocą dla każdego człowieka mają stać się żyjące dziś między nami wspólnoty monastyczne. Z nich człowiek współczesny ma czerpać siły i tam zdobywać umocnienie do odważnego świadczenia w środowisku swojego codziennego życia, o pokoju, którego fundamentem jest chrześcijaństwo. Tego rodzaju świadectwo wymaga konkretnych postaw, do których wezwany został każdy chrześcijanin. Postawy te mogą pociągać ludzi do wprowadzania pokoju. Jeśli tak się stanie, pokój Chrystusowy rozszerzać się będzie na wszystkie dziedziny ludzkiego życia ${ }^{40}$.

****

Na zakończenie należy jeszcze dodać, że w swoich wypowiedziach dotyczących św. Benedykta, papież Jan Paweł II wskazuje ustawicznie na wspólne cechy łączące świat Opata z Nursji z naszymi czasami. Toczące się w wielu zakątkach świata wojny, konflikty zbrojne, niepewność dnia jutrzejszego, upadek zasad moralnych, nieposzanowanie życia i godności człowieka oraz lęk - to problemy, z którymi boryka się także współcześnie wielu ludzi. Pewnego rodzaju ratunkiem na te bolączki był przed wielu laty św. Benedykt, który odważnie wyruszył na poszukiwania tego, co dobre i szlachetne. Głoszona natomiast przez niego nauka, staje się wyraźnym przesłaniem duchowym i społecznym dla współczesnego człowieka, dla całej jednoczącej się dzisiaj Europy, co tak często zauważał Jan Paweł II, kiedy mówił i pisał o św. Benedykcie.

O znaczeniu nauczania św. Benedykta dla dzisiejszych czasów można z pewnością mówić także w odniesieniu do modlitwy i pracy, które w życiu wspólnot benedyktyńskich posiadają ogromne znaczenie. Zauważył on bo-

38 Por. Homilia: Wasze klasztory wspólnotami prawdziwej miłości (20 IX 1980), OsRomPol 1 (1980) nr 12, s. 17; NP III/2, 355-358.

39 Przemówienie: Módlmy sięo pokój, wolność i sprawiedliwość (23 III 1980), przekład polski w: Aniot Pański z papieżem Janem Pawtem II, Rzym 1982, s. 214.

40 Homilia: Budować wspólny dom (18 V 1979), ,W drodze” 8 (1981) nr 1, s. 13. 
wiem potrzebę wprowadzenia równowagi pomiędzy pracą i modlitwą, życiem samotnym i wspólnotowym. Kiedy św. Benedykt wskazywał na szczególny charakter pracy, przywrócił jej tym samym właściwą godność. Nie można jej traktować wyłącznie jako elementu życia najniższych klas społecznych, ale należy dostrzec w niej środek prowadzący człowieka i całe narody do rozwoju duchowego.

\section{SAINT BENOÎT DANS L'ENSEIGNEMENT DE JEAN-PAUL II}

(Résumé)

En proclamant Saint Benoît, patron de l'Europe en 1964, Paul VI rappelait l'enseignement du Père des moines, par la force de son exemple et l'actualité de sa féconde devise: Prie et travaille. Le pape Jean-Paul II, qui a beaucoup écrit sur Saint Benoît (La Lettre Apostolique Sanctorum Altrix ; les discours et les homélies), nous rappelle ses titres: messager de paix, artisan d'union, maître de la civilisation et avant tout, héros de la religion du Christ et fondateur de la vie monastique en Occident. Dans l'enseignement de Jean-Paul II, saint Benoît a fait lever sur notre continent ,l'aurore d'une ère nouvelle". Il a mérité aussi d'être reconnu par Paul VI et Jean-Paul II, ,patron principal de toute l'Europe. Il convient de rappeler que l'Abbé Benoît enseigna aux hommes, la primauté du culte divin avec l'Opus Dei, c'est-à-dire la prière liturgique et assidue. C'est ainsi qu'il cimenta cette unité spirituelle de l'Europe, grâce à laquelle les peuples de langues, de races et de cultures diverses prirent conscience de constituer l'insigne peuple de Dieu. 